\title{
THE SETTLEMENT MORPHOLOGY ALONG MUSI RIVER: THE INFLUENCE OF RIVER CHARACTERISTICS
}

\author{
Maya Fitri \\ Department of Architecture, Sriwijaya University, Palembang, Indonesia \\ Email: mayafitrioktarini@gmail.com
}

\begin{abstract}
The study examined the morphology of the settements along the Musi riverbank and focuses on the association between the settlements morphology and the characteristic of the river. Musi River consists of three river zones, i.e. upstream, middle, and downstream. The specific morphology that was studied is the distance of the buffer area, the building orientation, and the housing typology that were compared to the physical characteristics of the river and the socio-cultural of the communities. The study data was collected through satellite map and field survey on three settlement sites for each zone, including maps, sketches, photographs, and interviews. The results show the main factors influencing the settlement morphology is the community's dependent on the river. The function of the river for daily life activities influences the distance, the orientation of the settlements, and the house tipology. The more the functions of the river for the daily life, the closer and the more oriented their settlements are to the river. Therefore, the river disasters, such as flood and erosion should keep the settlement away from the riverbank. However, the dependence on the river creates the building typology that adapt to the natural cycle. It all establishes the morphology of the settlements on the riverbank.
\end{abstract}

Keywords: Morphology; settlement; Musi river.

\section{INTRODUCTION}

Almost all cities in the world are developed along rivers bank or coastline. The history of urbanism has always been developed around to the water environment, although currently most of the urban development has been land-oriented due to the changes in the transportation way. Settlements along the river have benefited from the river's ecosystem service as an infrastructure for sanitation, drinking water needs, or transportation routes. In contrast to its function, river is also a source of flood or erosion disasters. The natural cycle of river ecosystems, such as tides, waves, and flow, that changes at any time requires a dynamic adaptation. The contradiction of the opposition and the controlling or the adaptation create the dynamics of the settlements morphology (Shannon, 2013; Pinke et al., 2016). The development on wetland in rivers bank is different from adaptation on land. The land natural cycle is more static, so development that controls to the atural cycle without damaging the land ecosystem is more suitable to be applied. The development along river banks that drain wetlands replace the ecosystem to the dry land. It reduces the function of the ecosystem services of the river bank that is important for the sustainability of the city.

The more sustainable development of the riverbank can be generated from the wisdom of vernacular people living on the banks of rivers. The vernacular people who live on riverbanks show their cultural manifestations of water interests (Papayannis, Pritchard, et al., 2011). The aquatic communities adapt and utilize these abundant water ecosystems. Instead of controlling water, this community lives in riverbank taking advantage of the tides and overflowing water. Tides refresh the water periodically in continuously. Overflowing floods carrying the land along the river and overflow of fish harvests. Work with nature rather than trying to control nature. In the daily life of the community of life depends on the river, water circulation patterns will influence the traditions of daily life and the form of settlements (Yodsurang, Hiromi, and Yasufumi, 2015).

The study identified the history of the vernacular settlements on the river banks. It was focused on the settlement patterns that are formed due to the development of culture, ecology, and technology in adapting the river ecosystems. It was also focused on the relationship between river characteristics and settlement patterns to recognize the influence factors. The planning of settlement on river bank should countervail the development needs, conserving the river ecosystem, with the socio-economic of the people. The equilibrium would create positives reciprocal between humans and the river ecosystems (Groffman et al., 2003) (Thaitakoo and McGrath, 2008).

The study was focused on three settlement morphology: the distance between the building and the riverbanks, the building orientation, and the typology of the residential building. First, providing distance between buildings and river is the most popular 
technique to maintain the ecology of river ecosystems. However, the distance depends on the situation, it is not the same and standard for all situations (Hawes and Smith, 2005). Second, the orientation of the building toward the river. The river which is on the front of buildings is more maintained than the one on the behind the building. The last, the building typology that to identify the community ways on the adaptation to dynamic river ecosystems.

There were several dissertations on similar studies, one of which is 'city's transformation along the Barito River'. It discussed the distance from settlements from the riverbank and the effects on settlements morphology (Mentayani, 2015). In cities dominated by rivers, the river ecosystems and surrounding made the image of the city. Not only the physical form, the city morphology also influenced by the activities of people that related to the river. It was discussed on the dissertation that examined the landscape morphology on Musi river banks that made the image of Palembang as the waterfront city (Anwar, 2013). The study on Lake Tempe focused on an assembling house to adapt to the river tidal. It discussed the dynamics of location, spatial, and inhabitation of the floating houses (Naing and Halim, 2013). Another study discussed the transformation of vernacular stilt and rafts houses of the river bank in Bangkok through recordings and documents (Denpaiboon, 2001).

\section{RESEARCH METHODS}

The study compared the physical characteristics and the socio-cultural of the settlement to the river characteristics. The research was the beginning of the studies to compile knowledge about sustainable riverbank settlements. It intended to prove the relationship of the social culture of aquatic communities creates the vernacular settlements that preserve river ecosystems. Based on it, the concept of riverbank settlement could be developed by modifying the patterns of vernacular settlements that are adapted to the needs of today's modern society.

The data were collected through a satellite map and survey which included maps, sketches, photographs of the settlement and the surroundings, and interviews with residents. The observation sites were located on the settlements along the banks of the Musi River, three settlement sites for each zone. Every site historically evolved around the river banks. The distance from the river banks and among sites and the density of settlements were the criteria of the site selection.

It observed the physical characteristics of a river bank in the settlements. Observations related to bank conditions, flow velocity, river width, and water clarity. Field observations measured the distance of the first and the second houses from the river banks. Physical observation also included the position of the main door and sketching the house plan. It was used to determine the orientation of the house. While the elevations and sections sketching of the house and the function of the building were used to identify building typologies. Besides that, observations also surveyed the daily activities of settlers associated with the river. The survey also observed changes in the house and the settlements over time. Observations were made through observation and interviews regarding the development of settlements and occupancy of the respondents.

Respondents were owners of houses whose houses stand on the banks of the river. The interview was arranged in open questions with topics that were limited to daily activities related to the river and their perception of the homes and settlements conditions. The interviews were equipped with the questions about the kind of river disaster and the impact on daily life, also the community response to the disaster.

\section{THE PHYSICAL CHARACTER OF MUSI RIVER}

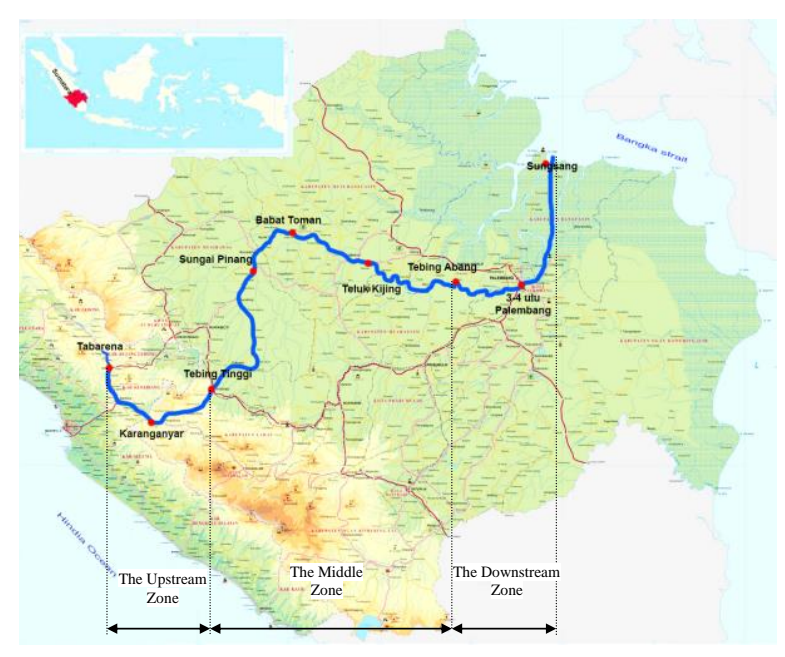

Fig. 1. Map of Musi river and the study locations (Redrawn by https://www.google.com/maps)

The ecosystem of Southern Sumatra is much influenced by rivers. The settlements evolved along the riverbank. Almost all big cities evolved at the intersection of several rivers (Charras, 2006). Musi River is the longest river in Sumatra and one of the largest islands in Indonesia. Musi River flows from the mountains in the western and high-altitude part of the island. Based on the river physical characteristics, the area on the Musi river bank can be divided into 
three zones, i.e. upstream, middle, and downstream (Samuel; Susilo Adjie 2008). Tabarena is the area where the first water spring. It flows toward Karanganyar and Tebing Tinggi that included in the upstream area. Sungai Pinang, Babat Toman, and Teluk Kijing are the middle area that surveyed. The downstream are Tebing Abang, 3-4 ulu Palembang and Sungsang. The Musi river ends on the estuary of the Bangka Strait in the eastern part of Sumatra Island (see Figure 1 and 2).

Taberena is the highlands village on the hills with an elevation of $\pm 700 \mathrm{~m}$ above sea level and is surrounded by the conservation forest. The zone is earthquakes prone, has a length of $\pm 187 \mathrm{~km}$ and flows through plantation fields, agriculture areas, settlements, and ends at Muara Kelingi. The upstream river has clear water with a depth between 30 and 80 $\mathrm{cm}$. The discharged water highly depends on rainfall with relatively small influence from water tidal. The land topography constructs steep straight-river and with water velocity of about $1.0-1.2 \mathrm{~m} / \mathrm{sec}$, it produces rafting conditions with rock bed and erosion along the river edges. The stream is often interrupted by an extreme gap of land elevation that creates the waterfall. The characteristic is less suitable for an aquatic biota; accordingly, upstream people do not rely on fishery but on agriculture and plantation. The volcanic soil with a cool climate is ideal for agriculture products, such as coffee, tea, wood, resin, and rattan. The upstream river cannot be used as water transportation; therefore, in the past, the community used boats to descend the mountain through Bukit Barisan to the stream in the foothill toward the city in Palembang (Santun, Murni, and Supriyanto, 2010).

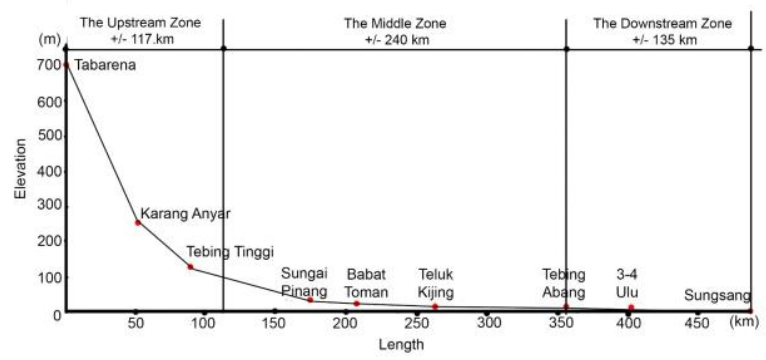

Fig. 2. Horizontal profile of Musi River from upstream to downstream

The middle zone of Musi river ranges from Muara Kelingi to Tebing Abang with a length of about $177 \mathrm{~km}$ and an elevation between $15 \mathrm{~m}$ to $40 \mathrm{~m}$ above the sea level. It is in lowland on the mountain foot where several streams join the Musi River at a medium velocity which reduces erosion. The river bed is filled with sediment and the river edge still has a firm boundary between water and land surface. The topography is relatively flat with many water traps creating swamps so that the river condition is much influenced by the swamp around. The sloping topography flows the stream at medium speed creating a meander with a wide river. The deep and wide river with a slow velocity and warm temperatures is an ideal habitat for an aquatic life. The river in the middle zone also functions as water transportation.

The downstream zone that flows from Tebing Abang to Bangka Strait in Sungsang, is part of the river that reaches the sea. Its length is about $146 \mathrm{~km}$ and it is very flat topography with an elevation between 15 to $0 \mathrm{~m}$ above sea level. During the rainy season, the river inundates the surrounding. It creates swamps and delta wetlands. The river velocity is very slow because of the almost flat topography and the backflow of the tides from Bangka Strait. The river deposits sediment along the stream such as mud, sand, and clay. In this zone, river has several junctions. The river network integrates all the trade routes from various agriculture and plantation areas. It is a strategic place for trading. Most people in the downstream zone work as traders (Nurhan, 2010).

\section{THE SETTLEMENT'S MORPHOLOGY ON MUSI RIVERBANK}

There are nine studied locations on the three Musi zones. The survey results show comparision of the site layout and the schematic cross-section of the settlements. The site lay out is used to identify the changes and similarity of the settlements morphology in the same zone or with other zones. It is also used to identify the influence of the width and shape of the river to the settlement morphology on its banks. Whereas, the section shows the width and depth of the river, the character of the riverbed, and the shape of the banks due to the flow. In addition, it is also show the influence of the characteristics of the river on the settlement morphology on its banks.

\section{The Settlement Morphology in the Upstream Zone}

The three sites in the upstream zone were Tabarena, Karang Anyar, and Tebing Tinggi. Tabarena was a village located at an altitude of $700 \mathrm{~m}$ above sea level with a width of about $35-45 \mathrm{~m}$, the river flowed from Tabarena down to the forest hills through the next site at Karang Anyar, $\pm 54 \mathrm{~km}$ away at an altitude of $220 \mathrm{~m}$. The large gap of the altitudes flowed the stream rapidly with brought out small sediments and left rocks on the river beds. From Karang Anyar, the river flowed through the plain area 
between two foothills. Then, the stream split and bent towards the third site at Tebing Tinggi, located \pm 30 $\mathrm{km}$ from Karang Anyar at an altitude of $125 \mathrm{~m}$. In this area, the stream velocity was slower than the two previous sites.

The upstream people did not much depend on the river for household needs. Instead, they obtained household water from water springs. Therefore, the river becomes the main source of clean water in the dry season. Since it was a shallow and narrow river, it was not suitable for water transportation. Meanwhile, at Tebing Tinggi where the river became bigger and deeper, fishery became a seasonal income in the rainy season as the river discharged increases. In Tebing Tinggi, the river was wide enough for water transportation, but it was often disturbed by siltation. Therefore, boats were only used to cross the river instead of reaching distant places.

The observation showed the different morphology on each site. In Tabarena, the settlement arrangement was much influenced by topography. People searched for relatively flat land to build houses. It composed the settlement in organic pattern. The house's site was kept away from the river edge to avoid erosion and inundation. When the rain comes, the river flow could suddenly increase and caused overflowed that inundated the surrounding area. However, it was fast absorbed, so there was no flooding in the settlements. To avoid the heavy river flow, people preferred built houses that close to the river branch than the main river. The branch river had slower velocity and fresher water. The constructions and structures of the houses were established to the anticipation of an earthquake. The houses were built on a stone foundation with lightweight materials and non-rigid structures, usually wood or mashed bamboo with plaster.

In Karang Anyar, the river velocity and the earthquake threat had declined. The houses were built closer to the river and built on stilts foundations to anticipate the water surface flows and frequent overflow flooding. The structure and construction of most houses used woods. Although the settlement was not directly oriented to the river, the layouts were combination of the parallel to the river and the contour of topography.

Whereas in Tebing Tinggi, the topography flatter than two other sites. Tebing tinggi is the end of upstream zone. The river character more resembling the middle zone. The layout of the site was a combination of the line of the topography and the river edge. Some houses were oriented toward the river. Recently, besides the stilts houses, there was another new typology house: two-storey shop house that built with brick wall and concrete structures. In contrast to the vernacular houses, the new shop houses were built only 5-10 m from the river edge and used heavy material. Not an only on the building, the river edge also was reinforced with concrete structures. It indicated only slight flooding and earthquake on the area.
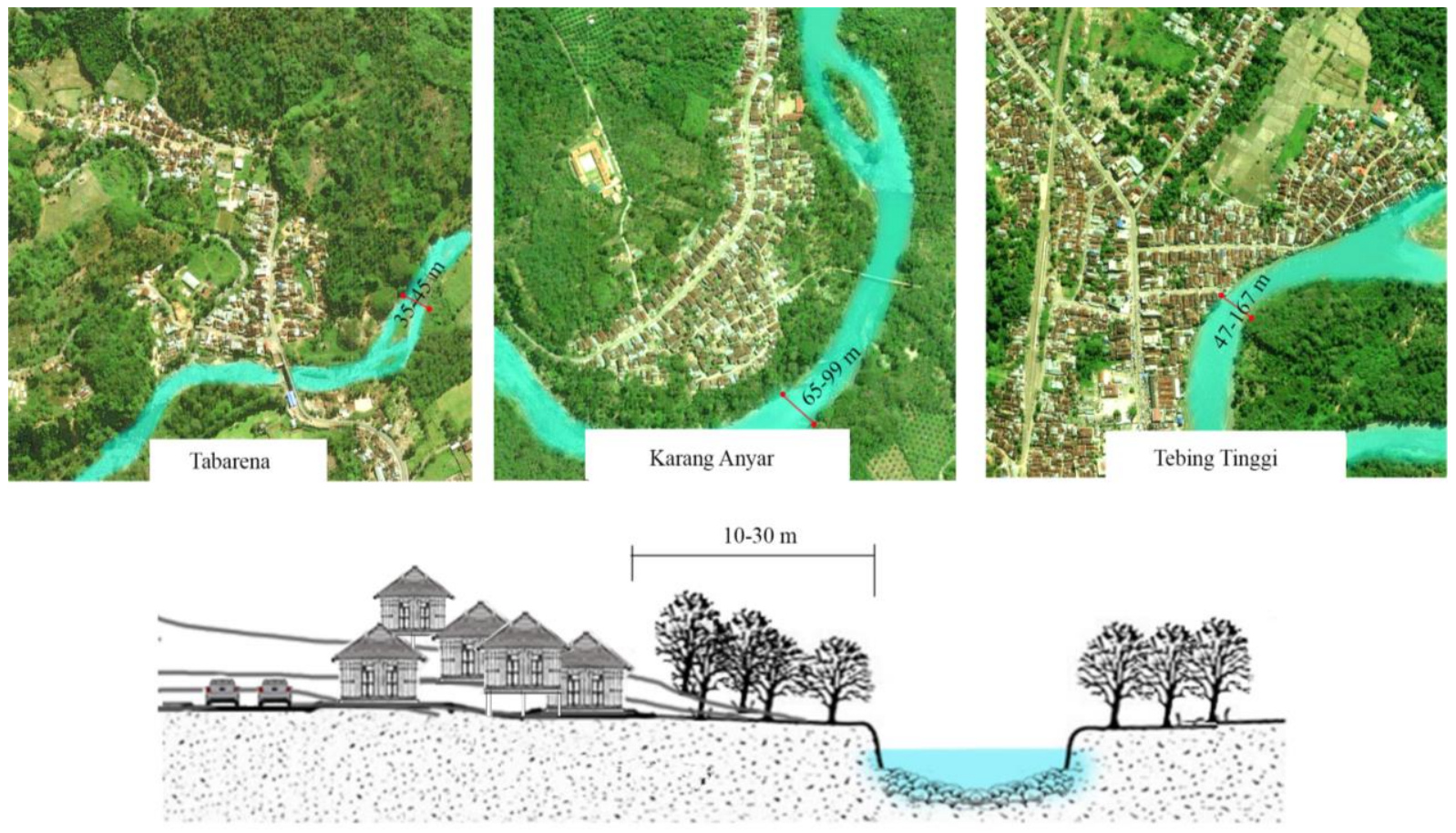

Fig. 3. The site layout and schematic section of settlements in the upstream zone (source: www.viamichelin.com) 


\section{The Settlement Morphology in the Middle Zone}

The three sites in the middle zone were Sungai Pinang, Babat Toman, and Teluk Kijing. The distance between Tebing Tinggi and Sungai Pinang was \pm 80 $\mathrm{km}$ and the distance between Babat Toman and Teluk Kijing was $62 \mathrm{~km}$. Contrast to the site distance that totally was $142 \mathrm{~km}$, the elevation gap of the three sites was only about $23 \mathrm{~m}$.

In middle zone, people utilized the river for various needs. The River was a source of fishery, wetland agricultures, water transportations, and households water. Agriculture and fishery were the main sources of people livelihoods. They did the farming by relying on the river overflows besides the rainfall. Babat Toman and Teluk Kijing were two villages that famous as fish producers in South Sumatra. The fishes were produced either in waterway or in an aquaculture. While the people in Babat Toman more relies on fishery from the waterway by trapping the fish on the swift stream, the people in Teluk Kijing more rely on the aquaculture.

River transportation began often used in Muara Kelingi, the city before Sungai Pinang. From Muara Kelingi, trade boats carried goods that connecting the settlements and plantations along Musi. Along the route, there were raft houses used as warehouses for agricultural and fishery product. In addition to the warehouses, there were also lined up the raft for washing, bathing, and latrine on the river. Although there was a clean water supply from public infrastructure, people still did the activities in the river.

The houses were built along the riverbank oriented toward the river. Each the riverfront house had two faces; the back elevation towards the river and the front elevation toward the road. Closer to the downstream zone, the settlements are built closer to the river edge. There was a buffer area in the settlement on Sungai Pinang, but no buffer area in Teluk Kijing. The houses built closer than $5 \mathrm{~m}$ from the river edge.

The houses were built as stilt buildings to anticipate flood because of the river overflow or tides. Formerly, people did not perceive flood as a disaster. The flood had brought abundant fishes and shrimps that drifted by heavy streams. The river overflow also had created a fertile land for farming. Unfortunately, the fishery dan agriculture did not give a lot of product anymore. It had decreased due to environmental damage. Besides that, the land transportation also developed, so people shifted transportation since it is more economical and efficient. Then, their houses were modified to fit activities that used land transportation. The empty space under the stilt house was modified as rooms. As a result, the houses were no longer adaptive to flood conditions. It changed people perception of the floods from a blessing into a disaster.
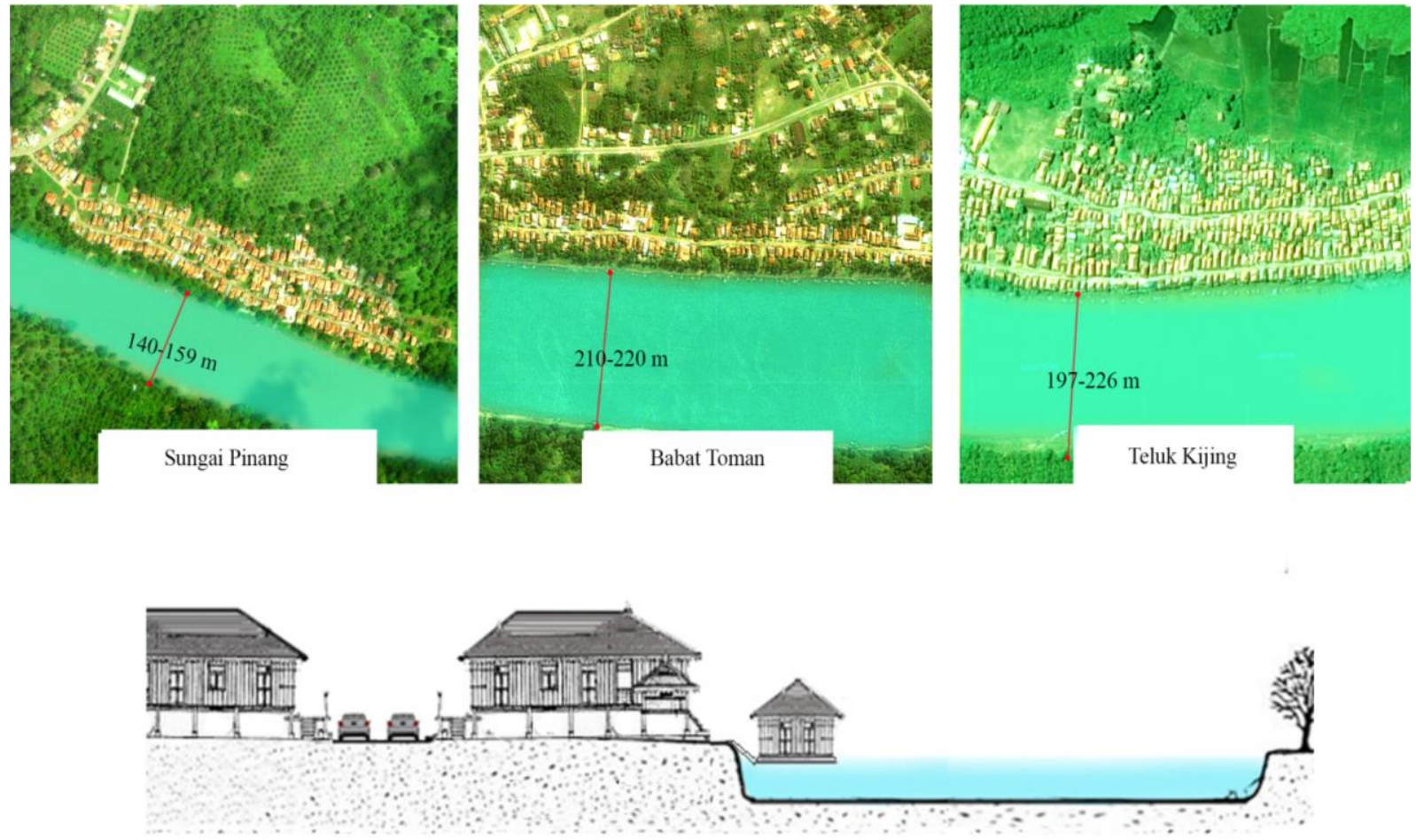

Fig. 4. The site layout and schematic section of settlements in the middle zone 

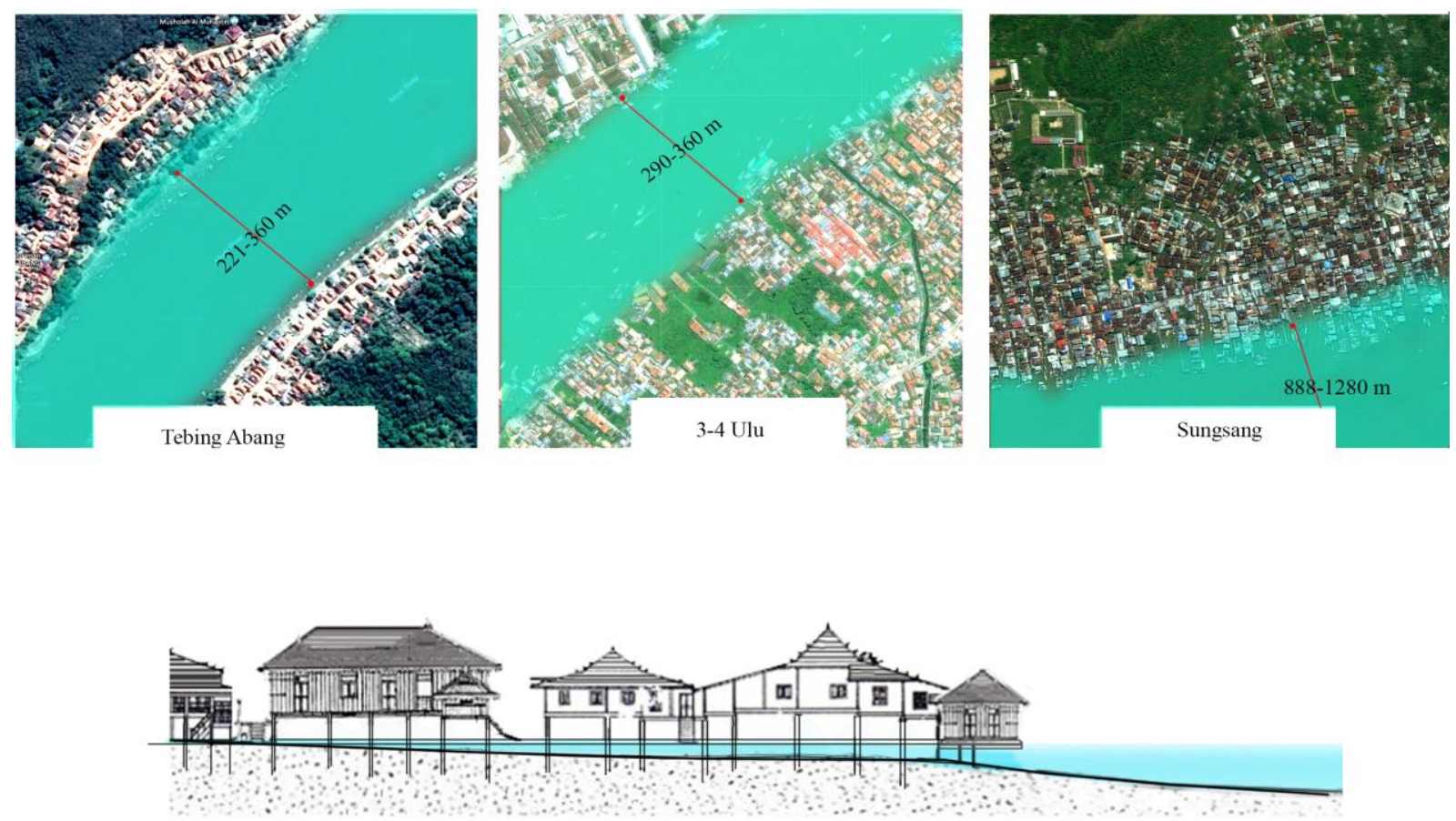

Fig. 5. The site layout and schematic section settlements in the downstream zone

The downstream zone began in Tanah Abang at an elevation of $7 \mathrm{~m}$ and ended at Sungsang Village that almost parallel to sea level. It was the meeting point area between the rivers and the ocean. The river in the downstream zone was very wide so there no clear boundary between land and water. The river edge was a slope with slow velocity so that erosion was rare. The settlements were usually developed at the junctions of several rivers. Tanah Abang was located at the junction of Musi river with a Musi river branch, Palembang was located at the junction of three major rivers with Musi river, while Sungsang was located at the estuary of Musi dan Telang rivers. The junction of three rivers (Komering, Keramasan, and Ogan) triggered Palembang to be the capital of South Sumatra since those rivers connected to most areas in Southern Sumatra.

In the downstream zone people livelihoods depended much on the river. It was the source of daily water, fishery and trade transportations. The settlements were built along the wetland on the river bank that directly connected to the river transportation. The riverfront houses had two faces with the main face was directed to the river. Formerly, each riverfront house had a terrace with boat dock. The houses were connected by long bridges on stilts. The houses stood on the wetland that was always inundated, therefore, it was built on a stilt or rafts foundation. Later, when people were no longer dependent on the river as used to be, the function of raft house was changed only a stall for selling fuels or others boat needs.

The layout of the site showed that the nearest road from the river edge was separated by dozens of houses and was built to hundreds of meters away. Although at Tanah Abang, the settlement morphology lined along the river bank resembling the middle zone morphology, it showed the increasing number row of houses at some site parts. The downstream morphology has fully configured at 3-4 ulu in Palembang. Moreover, at Sungsang, where most of the population were fishermen, the settlement has been integrated into the river. There was only one road to the village and there were docks along the river edge which indicates the importance of the riverway in Sungsang.

\section{SUMMARY AND CONCLUTION}

The results showed that there were differences in settlement morphology in the three Musi zones. This is found in the width of the buffer area, orientation, and building typology. The main factor affecting the three aspects of settlement morphology is people's dependence on river functions. Rivers are sources of clean water, fertile land, fishery, and transportation routes. Each zone has a different level of dependence on the river (see Table 1). It is the most important 
factor, even natural disasters such as floods and erosion which in many cases make settlements away from. It creates different respond when the people very dependent on the river. People prefer to build settlements that adapt to the disasters from the river. The river functions as a source of their lives are far more important than the disaster from the river.

Table 1. The settlement morphology in three zones

\begin{tabular}{|c|c|c|c|}
\hline & \multicolumn{3}{|c|}{ River Zone } \\
\hline & Upstream & Middle & Downstream \\
\hline $\begin{array}{l}\text { The people } \\
\text { dependency } \\
\text { on the river }\end{array}$ & $\begin{array}{l}\text { Daily water in } \\
\text { dry season }\end{array}$ & $\begin{array}{l}\text { nDaily water, } \\
\text { River Bathing } \\
\text { and Washing, } \\
\text { Transportation } \\
\text { way, Wetland } \\
\text { Agriculture, } \\
\text { Fishery }\end{array}$ & $\begin{array}{l}\text { Trade } \\
\text { transportation } \\
\text { route, Daily } \\
\text { water, River } \\
\text { Bathing and } \\
\text { Washing, } \\
\text { Fishery }\end{array}$ \\
\hline $\begin{array}{l}\text { Width of } \\
\text { Buffer Area }\end{array}$ & $>30 \mathrm{~m}$ & $0-5 \mathrm{~m}$ & - \\
\hline Building & Road or Land & 1 Land (main) & River (main) \\
\hline Orientation & Topography & and River & $\begin{array}{l}\text { and Plaza on } \\
\text { land }\end{array}$ \\
\hline $\begin{array}{l}\text { House } \\
\text { Typology fol }\end{array}$ & $\begin{array}{l}\text { Earthquake } \\
\text { resistant }\end{array}$ & $\begin{array}{l}\text { Stilts and rafts } \\
\text { houses to adapt }\end{array}$ & $\begin{array}{l}\text { Stilts and rafts } \\
\text { houses to }\end{array}$ \\
\hline $\begin{array}{l}\text { Adaptation } \\
\text { of Disasters }\end{array}$ & $\begin{array}{l}\text { Houses that } \\
\text { built away } \\
\text { from the river } \\
\text { erosion and } \\
\text { river flooding }\end{array}$ & $\begin{array}{l}\text { erosion and } \\
\text { river flooding }\end{array}$ & $\begin{array}{l}\text { adapt erosion } \\
\text { and river } \\
\text { flooding }\end{array}$ \\
\hline
\end{tabular}

In the upper-stream zone, which is a source of springs, settlements are built far from the banks of the river. It is because the residents do not depend much on the river. The settlements are separated from the river by fertile trees which also preserve the river from sedimentation and pollution of the household. Indirectly, it is appropriate to the concept of sustainable development to maintain the source of river springs on the upstream zone. It also reduces the effects of river disasters into settlements, such as erosion, flooding, or drifting. While in the middle zone, settlements are built exactly on the river edge. It is contrary to the fact that although the threat of erosion decreases and the possibility of flooding increases. It indicates the people much depend on the river as a source of livelihood and daily needs. Moreover, in the downstream zone, the settlements are built directly on the tidal riverbank area. There is no strict boundary between settlements and rivers. In this zone, people adapt to the natural cycle em because the river is very influential for their livelihoods and daily needs.

The dependence on river function not only determines the distance of the buffer area, but also the orientation of the buildings. The settlement orientation changes gradually from the upstream to the middle until the downstream. The settlements in the upstream zone are not oriented to the river. The layout of the building is adjusted to topography and circulation path of the land. In the middle zone, every riverfront house has two faces with the main direction is to the land. While in the downstream zone, the riverfront house has two faces with the main orientation to the river. It indicates that the higher the level of river dependence the more the settlement will be oriented to the river.

People's dependence on rivers influence their adaptation manifested in the typology of the building. In the upstream where river functions have little effect on people's lives; people avoid the erosion by keeping away the settlement from the river banks. The construction of the houses was addressed to encounter an earthquake. Despite threat the flood, people in the middle zone built the houses exactly on the riverbank. People constructed the stilt house to avoid disaster of the river flooding. It also avoids house from the disturbance from surface flows. In the downstream zone, people built the houses that suit tidal river. Besides the stilt house, people build the raft house that adapt the tides.

The development will be more sustainable if people and rivers have mutual ties with each other. The dependence on rivers is the basis of development that more adaptable to river ecosystems. The vernacular settlements had a concept that flexible to the natural cycle of the river ecosystem. The evolution of building technology and the river ecosystem damage reduce the community dependence on the rivers. It also shifts the community perception on the natural cycle of the river ecosystem from sources of life to disasters. The development also shifts from adapting to avoiding or controlling and changing the ecosystems. The non-binding between people and their ecosystem creates continuous damage. Contrary to the communities that depend on the river, they will maintain the natural ecosystem as the livelihoods. It finally configures the reciprocal process between people and ecosystem that create the sustainability development.

\section{REFERENCES}

Anwar, W. F. (2013). Identification of the Morphological Characteristic of Palembang Riverside Settlement. Universiti Teknologi Malaysia.

Denpaiboon, C. (2001). Transformation by Modernization of the Traditional Waterfront Settlements in the Context of Their Coexistence with Aquatic Environment: A Case Study of Raft House and Pillar House in Thailand. Kyoto University. 
Hawes, E., \& Markelle, S. (2005). Riparian Buffer Zones: Functions and Recommended Widths. Eightmile River Wild and Scenic Study Committee 15: 2005.

Groffman, P. M., Daniel J., Bain, L.E., \& Band, et al. (2003). Down by the Riverside: Urban Riparian Ecology. Front Ecol Environ 1(6), 315-321.

Mentayani, I. (2015). Transformasi Adaptif Permukiman Tepi Sungai di Kota Banjarmasin Kasus: Barito-Muara Kuin, Martapura, dan Alalak. Universitas Gadja Mada

Naing, N., \& Haryanto, H. (2013). Sistem Struktur Rumah Mengapung di Danau Tempe Sulawesi Selatan Structure System of Floating House at Tempe Lake in South Sulawesi. Jurnal Permukiman, 8(3), 143-152.

Nurhan, K. (2010). Jelajah Musi: Eksotika Sungai di Ujung Senja. Jakarta: PT. Gramedia. 2018.

Papayannis, T., Pritchard, D., and Mediterranean Institute for Nature and Anthropos (2011). Culture and Wetlands in the Mediterranean: An Evolving Story. Athens: Med-INA.

Pinke, Z., László, F., Gyula, G., \& Balázs, N. (2016). Settlement Patterns as Indicators of Water Level Rising? Case Study on the Wetlands of the Great Hungarian Plain. Quaternary International, 415, 204-215.
Samuel, \& Susilo, A. (2008). Zonasi, Karakteristik Fisika-Kimia Air dan Jenis-Jenis Ikan yang Tertangkap di Sungai Musi, Sumatera Selatan (Zonation, Physio-chemical Characteristic of Water and Fish species of Musi River). Jurnal Ilmu-Ilmu Perairan dan Perikanan Indonesia, 15(1), 41-48.

Santun, D.I., Muhammad, Murni, \& Supriyanto. (2010). Ilirin Dan Uluan: Dinamika Dan Dikotomi Sejarah Kultural Palembang. Yogyakarta: Eja Publisher.

Shannon, K. (2013). Eco-Engineering for Water: From Soft to Hard and Back. In Resilience in Ecology and Urban Design, S.T.A. Pickett, M.L. Cadenasso, and Brian McGrath, eds. 163182. Future City. Dordrecht: Springer Netherlands.

Thaitakoo, D., \& McGrath, B. (2008). Changing Landscape, Changing Climate: Bangkok and the Chao Phraya River Delta. Places, 20(1), 30-35.

Yodsurang, P., Hiromi, M., \& Yasufumi, U. (2015). A Traditional Community in the Chao Phraya River Basin: Classification and Characteristics of a Waterfront Community Complex. Asian Culture and History, 8(1): 57. 